\title{
Bell's Palsy with Preeclampsia in Pregnancy
}

\author{
Yeshey Dorjey ${ }^{1}$ \\ ${ }^{1}$ Royal Government of Bhutan Ministry of Health Department of Public Health
}

February 19, 2022

\begin{abstract}
Bell's palsy in pregnancy is not frequently seen. The association of preeclampsia with Bell's palsy is reported in the research, however, the exact link between Bell's palsy and preeclampsia is unknown. The treatment of Bell's palsy during the pregnancy is difficult and controversial.
\end{abstract}

\section{Hosted file}

Manuscript.docx available at https://authorea.com/users/419807/articles/557086-bell-s-palsywith-preeclampsia-in-pregnancy 